\title{
Aging affects the retinoic acid and the triiodothyronine nuclear receptor mRNA expression in human peripheral blood mononuclear cells
}

\author{
C Feart, V Pallet, C Boucheron, D Higueret ${ }^{1}$, S Alfos, L Letenneur ${ }^{2}$, J F Dartigues ${ }^{2}$ and P Higueret \\ Unité de Nutrition et Signalisation Cellulaire (E.A. MENRT, Usc INRA) ISTAB Avenue des Facultés Université Bordeaux 1,33405 Talence, ${ }^{1}$ Service de \\ Biochimie de l'Hôpital Pellegrin, Hôpitaux de Bordeaux, Centre Hospitalier Universitaire de Bordeaux, Place Amélie Raba Leon, 33000 Bordeaux and \\ ${ }^{2}$ INSERM U593 Université Victor Ségalen Bordeaux 2, 146 Rue Leo Saignat, 33076 Bordeaux Cedex, France
}

(Correspondence should be addressed to V Pallet; Email: v.pallet@istab.u-bordeaux1.fr)

$C$ Feart and $V$ Pallet have contributed equally to this work

\begin{abstract}
Background: Inadequate retinoid status has often been described as occurring with aging. Moreover, subclinical hypothyroid status has also been evoked in the elderly. Several studies performed in animals have described the crucial incidence of age-related hypo-functioning of retinoid and thyroid signalling pathways, particularly in the brain.

Objective: The aim of the present study was to clarify whether aging modifies retinoid and thyroid signalling in humans.

Methods: Using real-time RT-PCR the relative amount of mRNA of the retinoid (RAR $\alpha, \operatorname{RAR} \gamma$ and $\mathrm{RXR} \alpha$ ) and thyroid (TR $\alpha$ and $\mathrm{TR} \beta$ ) nuclear receptors in peripheral blood mononuclear cells (PBMC) of young (24-57 years old, $n=22)$ compared with elderly (69-90 years old, $n=24)$ healthy subjects was quantitated. Classical plasma parameters used to characterize the retinoid and thyroid status - retinol $(\mathrm{ROH})$, retinol-binding protein (RBP), free triiodothyronine (FT3) and thyroxine (FT4), thyroid-stimulating hormone (TSH) and transthyretin (TTR) - were also assessed. Results: RAR $\gamma$ expression was significantly decreased in elderly versus young subjects while no modification of the retinoid-related plasma parameters ROH and RBP were emphasized by aging. Concerning thyroid criteria, the elderly exhibited an increase in TSH concentration $(+39 \%)$ without significant modifications of FT3 and FT4, which indicated an age-related sub-clinical hypothyroidism. Concurrently, the amount of TR mRNA ( $\alpha$ as well as $\beta$ subtypes) was significantly decreased in the elderly. Conclusion: These data constitute the first evidence of an age-related hypo-activation of the retinoid and thyroid nuclear pathways in PBMC. Further study of the possible association between the expression of the retinoid and thyroid nuclear receptors and age-related cognitive alterations in humans would be interesting.
\end{abstract}

European Journal of Endocrinology 152 449-458

\section{Introduction}

The aging process is a heterogeneous and inevitable phenomenon involving the whole organism. The life expectancy and the number of elderly persons are increasing in industrialized countries, largely as a consequence of improvements in health care (1). These observations contribute to the development of recent research on human aging mechanisms (2-5).

Hormones, some soluble mediators of the inflammatory response, free radicals, anti-oxidants, and macroand micro-nutrients associated with aging-linked health damage, have been defined as potential markers of aging $(6,7)$. Among them, the markers involved in the status and function of vitamin $\mathrm{A}$ and thyroid hormones have been the subject of considerable interest
(8-10). Alterations in retinoid metabolism and thyroid dysfunction occur with senescence. Age-related alterations in vitamin A metabolism, particularly plasma retinol $(\mathrm{ROH})$ concentration have been reported in rats and humans $(11,12)$. Vitamin A deficiency has also been identified in elderly subjects (13). In addition, changes in thyroid function are often described in elderly people. There are reports of similarities between the signs of hypothyroidism and clinical features of healthy elderly subjects (14) and increased thyroid-stimulating hormone (TSH) secretion with aging $(10,15)$. Finally, in old people, plasma $\mathrm{ROH}$ is negatively associated with free thyroxine (FT4) and TSH serum levels (15). All these data suggest an age-related alteration of vitamin A and thyroid status. Numerous links between diseases or disorders occurring with aging 
and alterations in these states have been evoked in the literature. Comparisons between healthy centenarians and younger (80 years old and less) subjects has shown that very old people exhibit significantly higher plasma ROH levels (9).

Recently, Goodman and Pardee (16) reported an association between the late onset of Alzheimer's disease and abnormal retinoid metabolism. Moreover, several studies have also reported that dysfunction of the thyroid gland is a common clinical disease associated with aging (17-20). Investigations into the relationships between thyroid status and cognitive abilities in humans have shown that a deficit in thyroid hormones induces severe anatomic and functional alterations of the nervous system, and intellectual impairment (21-24).

However, in humans, little is known about agerelated modifications in the metabolism and signalling pathways of vitamin A and thyroid hormones. Vitamin A, and retinoic acid (RA) have a wide variety of profound effects on growth, epithelial tissue differentiation and homeostasis, and are involved in maintaining an efficient immune system (25). RA is able to partly regulate gene expression through binding to specific nuclear receptors: retinoic acid receptors (RARs) or retinoic $\mathrm{X}$ receptors $(\mathrm{RXR})(26)$. The $\operatorname{RAR}$ family $(\alpha, \beta, \gamma)$ is activated by both all-trans RA and by 9-cis RA, whereas the RXR family $(\alpha, \beta, \gamma)$ is exclusively activated by 9 -cis RA. These nuclear proteins are DNA-binding proteins, which belong to the superfamily of ligand-activated transcriptional regulators (27). Thyroid hormone nuclear receptors (TR $\alpha$ and TR $\beta$ ) are also members of the nuclear receptor superfamily and regulate target genes in response to the triiodothyronine (T3) ligand (the active form of thyroid hormones) $(28,29)$.

It has also been shown that RXR forms heterodimers with either RAR or TR in order to allow the regulation of gene transcription by interacting with distinct sequences in the promoter of target genes. Retinoids and thyroid hormone signalling pathways work in close relationship, particularly by means of RXR, which is the essential common partner for functional heterodimers for both pathways (30-32).

Studies performed in animals (rats and mice) have shown that aging is accompanied by hypo-activity of retinoid and thyroid signalling, measured as a hypoexpression of the nuclear receptors RAR, RXR and TR; this has been observed in several organs $(33,34)$, which confirms that the drop in retinoid and thyroid status affects the entire organism.

Therefore, taken together, previous studies on the functional significance of retinoid and thyroid signalling have lead us to hypothesize that optimal maintenance of physiological processes requires precise regulation of the activation of these pathways. Moreover, aging also seems to lead to a decrease in the availability of RA and $\mathrm{T} 3$ inside the cell, a decrease which would lead to hypo-expression of the nuclear receptors. This phenomenon, which has been demonstrated in animals, has not yet been observed in humans. Indeed, measurements of $\mathrm{ROH}$, thyroid hormones and peripheral concentrations of TSH performed in elderly populations do not reflect the intracellular availability of RA or thyroid hormones and thus the functional status of retinoid and thyroid signalling.

In order to assess the effects of aging on vitamin A and thyroid signalling pathways in humans, the expression of $\operatorname{RAR} \alpha, \operatorname{RAR} \gamma, \operatorname{RXR} \alpha, \operatorname{TR} \alpha$ and $\operatorname{TR} \beta$ in young versus healthy elderly subjects were compared. The amounts of mRNA in a more approachable tissue, peripheral blood mononuclear cells (PBMC), were quantified.

\section{Subjects and methods}

\section{Subjects}

Forty-six healthy men and women volunteers were recruited for this study: $22(24-57$ years old) in the young group (YG) and 24 (69-90 years old) in the elderly group (EG). Subjects for the YG were selected from volunteers according to their age, i.e. less than 60 years, and their health. We recruited only healthy subjects and tried to have equal numbers of men and women in this group. The subjects of the EG were selected from a large cohort, the Three City (3C) Study. This is a collaborative research program based on a cohort of 9294 subjects aged 65 years and over, recruited in three French cities. The cohort was randomly sampled from the electoral rolls and was supplemented by volunteers. Baseline data collection included socio-demographic variables, medical history, blood pressure, anthropometrical data, functional status of cognitive functioning, and past and present consumption of tobacco, alcohol and drugs. Among several psychometric tests, the mini mental score examination (MMSE) (35) was used to assess the cognitive performance of the subjects. At enrolment, neither young nor elderly subjects had chronic medical problems or illnesses associated with immune dysfunction. The study protocol was approved by the Ethical Committee of the University Hospital of Kremlin-Bicêtre (Paris, France). Each participant signed an informed consent form to participate in this study.

\section{Health status}

Venous blood was collected from all subjects after overnight fasting ( $\approx 12 \mathrm{~h}$ after previous meal). Diagnostic kits (RIA and IRMA, Immunotech, Marseille, France) were used to measure FT3, free thyroxine (FT4) and TSH concentrations. The plasma $\mathrm{ROH}$ concentration was determined by HPLC according to the method of Leclercq and Bourgeay-Causse (36). Plasma transthyretin (TTR) and retinol-binding protein (RBP) concentrations were measured using an immunonephelometric process (Nephelometer Analyser II; 
Behring Diagnostics Inc., Deerfield, IL, USA). Plasma total cholesterol (TC) and total triglyceride (TTG) concentrations were measured by an enzymatic method using a Synchron CX5 analyser (Beckman Coulter, Villepinte, France). It was not always possible to measure the plasma parameters for all the subjects.

\section{Preparation of PBMC}

Isolation of human (YG and EG) blood mononuclear cells was performed by density gradient centrifugation using Ficoll-Paque Plus solution (Amersham). After overnight fasting, venous blood $(5 \mathrm{ml})$ was drawn into an EDTA-coated vacutainer tube and layered onto $4 \mathrm{ml}$ Ficoll-Paque Plus solution and then centrifuged at $400 \boldsymbol{g}$ for $20 \mathrm{~min}$ at $20^{\circ} \mathrm{C}$. PBMC were removed from the plasma-Ficoll interface, washed twice in PBS (1 M, pH 7.2) to remove platelets, Ficoll-Paque and plasma. PBMC were then suspended in Trizol reagent (Invitrogen) for total RNA preparation.

PBMC from the YG and the EG were assayed simultaneously in all assays to ensure that differences between groups were indeed biological and not a result of inter-assay variation.

\section{Quantification of mRNA expression}

Total RNA preparation Blood mononuclear cells were directly homogenized in $1 \mathrm{ml}$ Trizol reagent solution and total RNA was extracted following the manufacturer's suggested protocol for small quantities of tissue. Purified RNA was quantified and assessed for purity by u.v. spectrophotometry. The average yield of total RNA extraction was not significantly different in PBMC from young or elderly subjects.

Reverse transcription and analysis of gene expression Reverse transcription and analysis of gene expression using a real-time PCR (PCR assay involving Light Cycler technology) were carried out as described by Redonnet et al. (37) with minor modifications specific to the gene studied. Specificity of primers was validated through the verification of RT-PCR product specificity. The identity of amplified products was verified by sequencing with the Dye Terminator Reaction Cycle kit (Perkin-Elmer, Norwalk, CT, USA) and analysed on an ABI PRISM 377 automated DNA sequencer (Perkin-Elmer).

According to the level of expression of each gene of interest, we used a specific housekeeping gene. Their levels of expression have to be comparable (less than five cycles of interval). Cyclophilin cDNA was used as housekeeping for the relative quantification of cDNA of $\operatorname{RAR} \alpha, \operatorname{RXR} \alpha$ and $\operatorname{TR} \alpha$, while porphobilinogen deaminase (PBGD) cDNA was used for RAR $\gamma$ and TR $\beta$. The forward and reverse primer sequences were as follows. For cyclophilin: forward, 5'-TCCTAAAGCATACGGGTCCTGGCAT-3'; reverse,
5'-CGCTCCATGGCCTCCACAATATTCA-3'. For PBGD: forward, 5'-TGCACGATCCCGAGACTCTGC-3'; reverse, 5'-GCACGGCTACTGGCACACTGC-3'. For RAR $\alpha$ : forward, 5'-CTGCCAGTACTGCCGACTGC-3'; reverse, 5'ACGTTGTTCTGAGCTGTTGTTCGTA-3'. For RAR $\gamma$ : forward, 5'-CTGCCAGTACTGCCGGCTAC-3'; reverse, 5'TCTGCACTGGAGTTCGTGGTATACT- ${ }^{\prime}$. For RXR $\alpha$ : forward, 5'-CGACCCTGTCACCAACATTTGC-3'; reverse, 5'-GAGCAGCTCATTCCAGCCTGCC-3'. For TR $\alpha$ : forward, 5'-GTTCTAGATGACTCGAAGGCGGG-3'; reverse, 5'-CTTCAGGAgTGGGCTCTGGTCG-3'. For TR $\beta$ : forward, 5'-CCGAAGCACTGTCCAGACCGAGAAC-3'; reverse, 5'-TCAAAGACTTCCAAGAAGAGAGGC-3'. The results were normalized by the ratio of the relative concentration of the target gene to that of the PBGD or cyclophilin sample. The real-time PCR method confirmed that the expression level of the housekeeping genes was unaffected by aging. It was not always possible to measure the relative amount of each nuclear receptor for all the subjects.

\section{Statistical analysis}

Data are expressed as means \pm S.E.M. All statistics were calculated using Statgraphics Plus software. The statistical significance of differences between means was calculated by ANOVA followed by Student's $t$-test; except for the TSH concentration for which the Kruskal-Wallis test was employed because the s.D. appeared to be different between the two groups. Linear regression was used to analyse the relationships between variables. Statistical significance was accepted at $P<0.05$.

\section{Results}

The sample studied comprised 16 men and 30 women. At inclusion, the mean age was 35.5 years (range, 2457 years) for the YG and 75.1 years (range, 69-90 years) for the EG. The YG included 12 (54\%) women and $10(45 \%)$ men. Among the elderly subjects, 18 (75\%) were women and six $(25 \%)$ were men (Table 1$)$. Several biological characteristics were different between the young and elderly, particularly the lipid parameters. As shown in Fig. 1, TC and TTG concentrations were significantly increased $(P=0.027$ and $P=0.014$

Table 1 Distribution of participants by gender and age.

\begin{tabular}{|c|c|c|c|c|}
\hline \multirow[b]{2}{*}{ Gender } & \multicolumn{2}{|c|}{ Young group } & \multicolumn{2}{|c|}{ Elderly group } \\
\hline & $n$ & Age (years) & $n$ & Age (years) \\
\hline Males & $10(45)^{a}$ & $34.9 \pm 12.1^{b}$ & $6(25)$ & $76.5 \pm 6.5$ \\
\hline Females & $12(54)$ & $36.1 \pm 11.0$ & $18(75)$ & $70.8 \pm 1.9$ \\
\hline Total & 22 & $35.5 \pm 11.3$ & 24 & $75.1 \pm 6.2$ \\
\hline Range & & $24-57$ & & $69-90$ \\
\hline
\end{tabular}

${ }^{a}$ Numbers in parentheses represent percentage of total.

${ }^{\mathrm{b}}$ Means \pm S.D. 
respectively) in the plasma of elderly subjects in comparison with the young group, although the values remained within the laboratory reference range.

\section{Retinoid status}

Serum ROH concentration was measured in order to characterize the vitamin A status of the subjects. No significant difference was observed between the YG and the EG. The variation in plasma RBP concentration, proposed as a simple surrogate measure for vitamin A assessment $(38,39)$, was not different in the EG as compared with the YG. These two parameters were, moreover, within the laboratory reference values, which indicated that all the subjects exhibited a normal nutritional status (Table 2). In the YG as well as the EG, the ROH concentration correlated very well with the RBP concentration $(r=0.80, P<0.0001)$.

The calculation of the RBP to TTR molar ratio (RBP:TTR) has been proposed as an indirect method for vitamin A assessment $(40,41)$. In this study, this ratio was significantly higher in the EG than in the YG $(+16 \%, P<0.001)$ (Fig. 2). TTR or prealbumin measurement was used as an indicator of the nutritional status. As shown in Fig. 1, the plasma TTR concentration was lower in the EG as compared with the YG $(-15 \%, P=0.003)$ (Fig. 2). Moreover, in the EG the TTR concentration was correlated with age $(r=-0.46, P=0.023)$. In the whole population we observed a correlation between TTR and ROH or TTR and RBP $(r=0.51, \quad P<0.001$ and $r=0.54$, $P<0.001$ respectively).

ROH was well correlated with RBP concentration, and also exhibited good correlation with the RBP:TTR ratio in the young subjects $(r=0.62, P=0.006)$. This correlation slightly decreased with aging $(r=0.48, P=0.031)$.

Several subtypes of retinoid receptors were found expressed in the human PBMC. The relative expressions of mRNA of $\operatorname{RAR} \alpha, \operatorname{RAR} \gamma$ and $\operatorname{RXR} \alpha$ are given to assess the intracellular functions of the retinoids. No significant difference was found between young and elderly subjects except for the RAR $\gamma$ isoform, the mRNA amount of which was significantly reduced in the PBMC of the EG as compared with the YG $(-16 \%$, $P=0.042$ ) (Table 3).
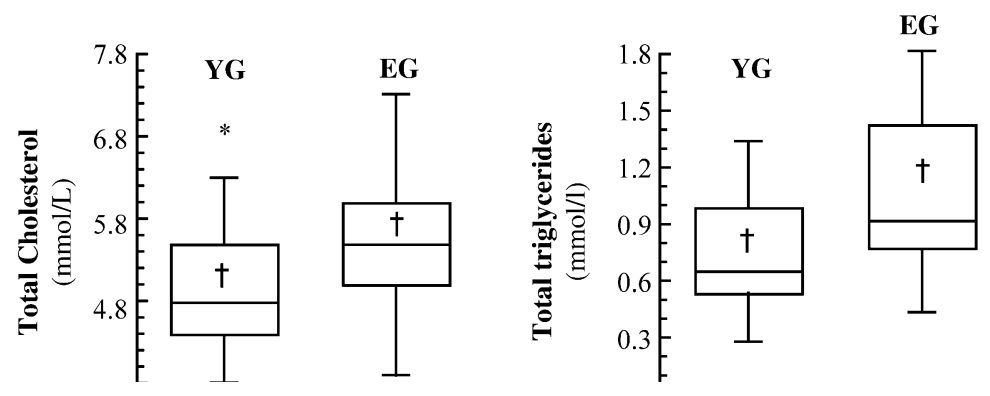

Figure 1 Plasma concentration of total cholesterol and total triglycerides in young and elderly groups. Statistical analyses performed using ANOVA followed by Student's $t$-test showed significant differences between young and elderly groups. $\dagger$, mean value; horizontal line in each box indicates the median; *value distant of two S.D. from the mean. 
Table 2 Plasma concentrations of ROH, RBP, and free thyroid hormones FT3 and FT4 in the young and elderly groups.

\begin{tabular}{|c|c|c|c|c|c|}
\hline & \multirow[b]{2}{*}{ Laboratory reference range } & \multicolumn{2}{|c|}{ Young group (total $n=22$ ) } & \multicolumn{2}{|c|}{ Elderly group (total $n=24$ ) } \\
\hline & & Mean \pm S.E.M. $(n)$ & Range & Mean \pm S.E.M. $(n)$ & Range \\
\hline Retinol $(\mu \mathrm{mol} / \mathrm{l})$ & $1.5-3.0$ & $2.09 \pm 0.08(20)$ & $1.5-2.6$ & $2.16 \pm 0.09(23)$ & $1.6-3.1$ \\
\hline $\operatorname{RBP}(\mu \mathrm{mol} / \mathrm{l})$ & $1.7-2.9$ & $2.03 \pm 0.09(19)$ & $1.4-2.7$ & $2.05 \pm 0.07(21)$ & $1.6-2.9$ \\
\hline FT3 (pmol/l/) & $2.5-5.0$ & $3.65 \pm 0.09$ & $2.9-4.3$ & $3.44 \pm 0.08$ & $2.9-4.4$ \\
\hline FT4 (pmol/l) & $10-20$ & $14.07 \pm 0.26$ & $11.7-16.4$ & $13.32 \pm 0.32(24)$ & $10.6-16.6$ \\
\hline
\end{tabular}

age-associated disorders is one of the highest priorities in industrialized countries. Knowing the extensive role of the retinoid and thyroid pathways in the physiology of adults and the elderly, particularly in the brain, the purpose of this study was to determine whether the abundance of retinoid and thyroid nuclear receptor isoforms is modified by aging in human PBMC.

\section{Retinoid status}

In the present study, when compared with the young group, elderly people did not exhibit any differences in the plasma parameters that traditionally characterize vitamin A status, namely the concentrations of $\mathrm{ROH}$ and RBP $(38,39)$. This situation has been observed previously $(15,42)$. The present study differs, however, from some others that have shown a higher retinol concentration in older subjects (9) or a gradual, linear increase in the average concentration of retinol with age (43); some other studies have described agerelated reduction in plasma retinol concentration $(11$, 13). Here, in young as well as in elderly subjects, the $\mathrm{ROH}$ concentration correlated very well with the RBP concentration $(r=0.80, P<0.0001)$. This is consistent with the 1:1 molar complex between RBP and ROH in plasma (44). Moreover, no subjects had a fasting plasma retinol concentration under $1.4 \mu \mathrm{mol} / \mathrm{l}$, a threshold assumed to indicate a moderate risk of vitamin A deficiency (45). The unimpaired vitamin A status of the subjects was confirmed by a RBP:TTR molar ratio higher than 0.37 in the entire population studied (young and elderly). This cut-off point $($ RBP:TTR $=0.37)$ was proposed in order to assess vitamin A deficiency in adults and children (40, 41).

Interestingly, the present data constitute the first observation of an age-related increase in this ratio; the implications of this remain uncertain. The variation in the ratio with age may be attributed, at least in part, to the decrease in the TTR concentration in the EG as compared with the YG. The correlation between age and TTR concentration evidenced in the EG was in agreement with the observation of Ingenbleek and De Visscher (46), who have shown such an age-dependent decrease in TTR after 50 years of age. Robbins (47) furthermore affirmed that the TTR concentration in plasma must be considered as a sensitive indicator of malnutrition and illness owing to a reduction in its production rate in combination with its very rapid rate of disappearance from the circulation. However, the TTR concentration in the YG and the EG remained within the laboratory reference limits.

Moreover, association of the ROH and the RBP concentrations with the RBP:TTR ratio confirmed this ratio as a good indicator of vitamin A status in adults.

\section{Expression of retinoid nuclear receptors}

In this study, the quantification of the expression of the retinoid nuclear receptors, which constitutes a reliable approximation of the real bioavailability of retinoids at the nuclear level in PBMC, was promoted. The results demonstrated that, even though $\operatorname{RAR} \alpha$ and $\operatorname{RXR} \alpha$
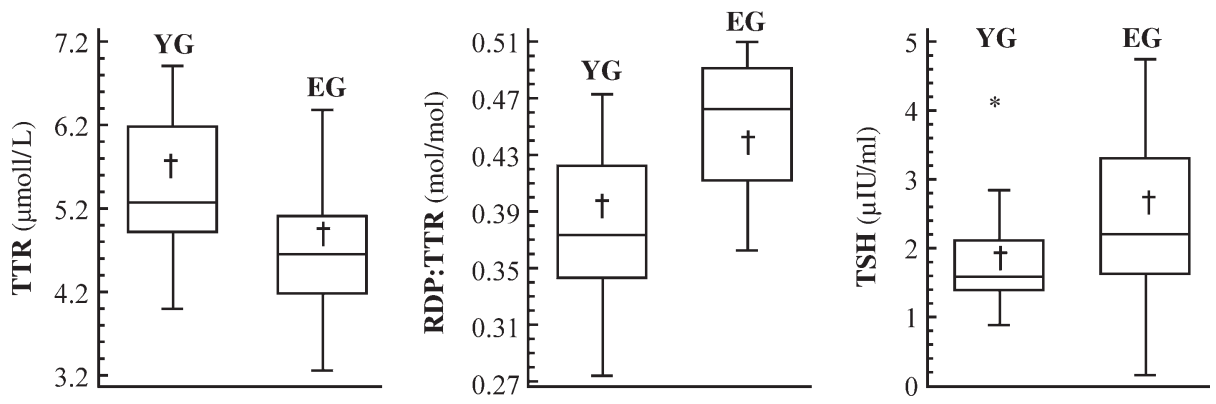

Figure 2 Plasma concentration of TTR, TSH and RBP:TTR ratio in young and elderly groups. Statistical analyses performed using ANOVA followed by Student's $t$-test for TTR and RBP:TTR and using Kruskal-Wallis test for TSH concentration showed significant differences between young and elderly groups. $\dagger$, mean value; horizontal line in each box indicates the median. 
Table 3 Effect of aging on the relative expression of RA and T3 nuclear receptors in human PBMC.

\begin{tabular}{|c|c|c|c|c|}
\hline & \multicolumn{2}{|c|}{ Young group (total $n=22$ ) } & \multicolumn{2}{|c|}{ Elderly group (total $n=24$ ) } \\
\hline & Mean \pm S.E.M. $(n)$ & Range & Mean \pm S.E.M. $(n)$ & Range \\
\hline $\operatorname{RAR} \alpha$ (\% cyclophilin) & $35.9 \pm 2.1(16)$ & $22-46$ & $31.6 \pm 1.5(23)$ & $20-44$ \\
\hline RAR $\gamma(\%$ PBGD) & $193.1 \pm 12.7(16)$ & $111-283$ & $162.1 \pm 6.9 *(21)$ & $100-217$ \\
\hline $\mathrm{RXR} \alpha$ (\% cyclophilin) & $25.2 \pm 1.1(12)$ & $20-30$ & $28.7 \pm 1.4(22)$ & $20-47$ \\
\hline TR $\alpha$ (\% cyclophilin) & $4.9 \pm 0.2(18)$ & $3.5-6.8$ & $4.3 \pm 0.1 *(21)$ & $3.2-5.3$ \\
\hline TR $\beta$ (\% PBGD) & $12.6 \pm 0.6(14)$ & $9.1-16.2$ & $10.3 \pm 0.6^{*}(23)$ & $6.2-14.8$ \\
\hline
\end{tabular}

Statistical analyses were performed using ANOVA followed by Student's $t$-test.

* Significantly different from young group, $P<0.05$.

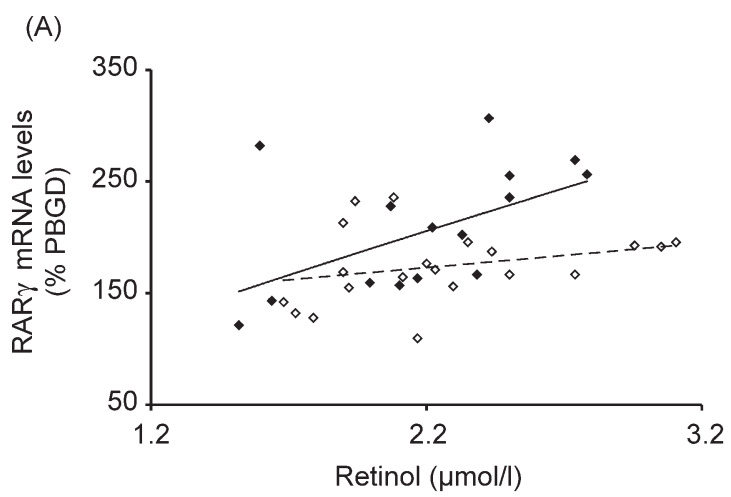

(B)

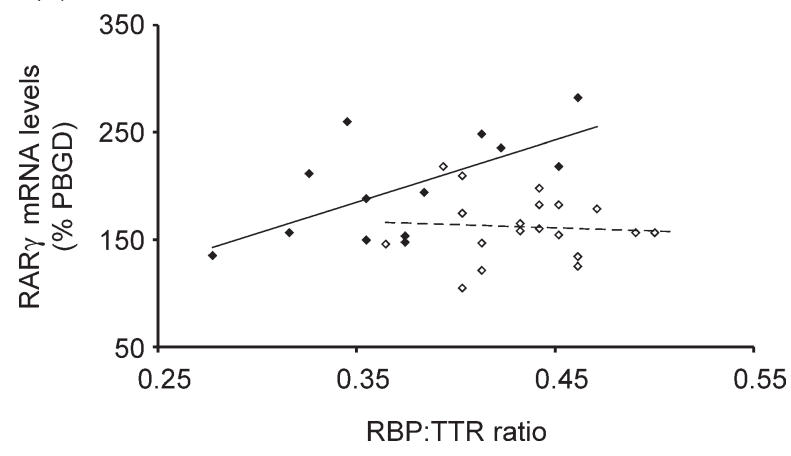

Figure 3 Correlation between RAR $y$ mRNA level in the PBMC and $(\mathrm{A})$ retinol concentration in young $(\bullet, n=15 ; r=0.52$, $P=0.045)$ and elderly subjects $(\diamond, n=20 ; r=0.38, P=0.08)$ or (B) RBP:TTR ratio in young $(\diamond, n=13 ; r=0.64, P=0.018)$ and elderly subjects $(\diamond, n=19 ; r=-0.07, P=0.78)$.

expression was not significantly changed in PBMC with aging, it tends to change toward down-regulation for $\operatorname{RAR} \alpha$ and to up-regulation for $\operatorname{RXR} \alpha$. The $\operatorname{RAR} \gamma$ expression was significantly reduced in the PBMC of elderly subjects relative to young subjects. These data constitute the first evidence of hypo-activation of the retinoid pathway in the elderly. They differ from emerging data reporting that, in order to maximize utilization of scarce ligand, aged human skin overexpressed $\operatorname{RAR} \alpha$ in a compensatory manner (48). While aging is usually associated with reduced RA bioavailability and lowered expression of receptors $(34,72)$, it appears that expression of retinoid receptors is particular to each specific tissue type.
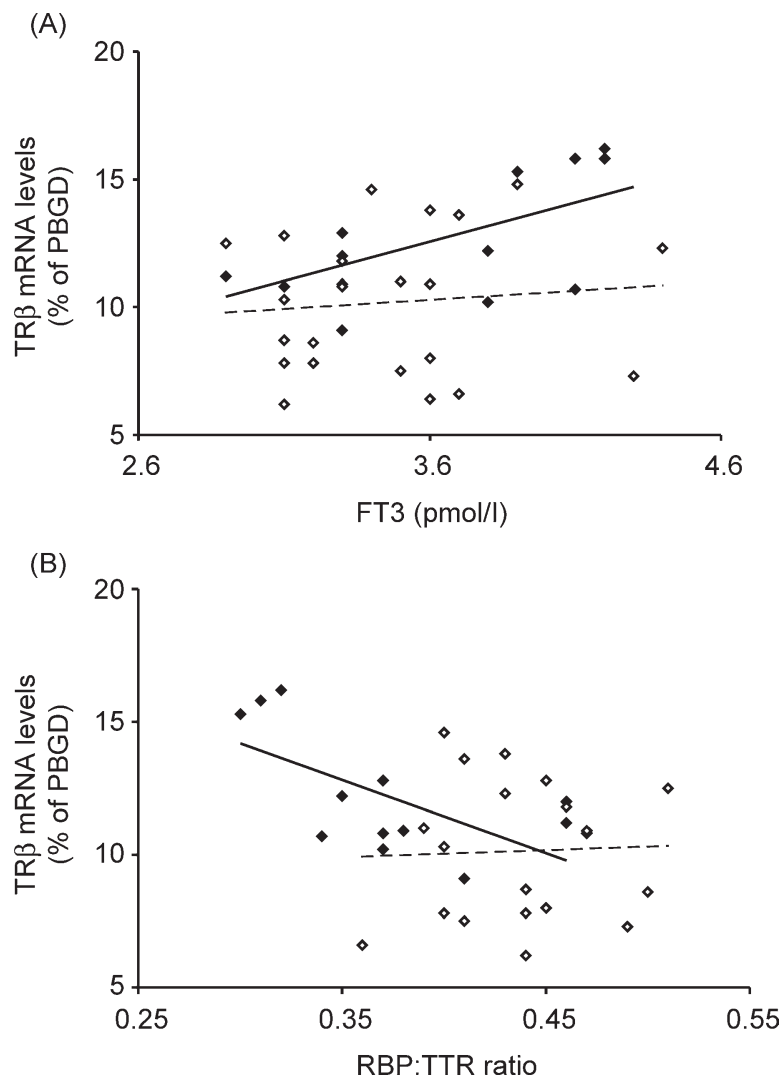

Figure 4 Correlation between TR $\beta$ mRNA level in the PBMC and (A) FT3 concentration in young $(\diamond, n=14 ; r=0.60, P=0.022)$ and elderly subjects $(\diamond, n=22 ; r=0.10, P=0.66)$ or $(\mathrm{B})$ RBP:TTR ratio in young $(\bullet, n=13 ; r=-0.62, P=0.031)$ and elderly subjects $(\diamond, n=19 ; r=0.04, P=0.87)$.

Moreover, although it was possible to show a strong correlation between the ROH concentration and RAR $\gamma$ expression in young people $(r=0.52, P=0.045)$, this correlation abated with aging $(r=0.38, P=0.08)$. Similarly, RAR $\gamma$ expression was closely related to the RBP:TTR ratio in the young but not in the elderly. It would seem that the potential association between the peripheral markers of vitamin A status and the retinoid function was no longer feasible in older people. This may indicate that aging reduces the nuclear bioavailability of RA, leading to an alteration in the function 
of the retinoid pathway not perceptible by measuring plasma parameters. Additionally, use of gene expression assays to assess vitamin A status instead of more classical analysis methods has already been proposed by Furr (49).

\section{Thyroid status}

The endocrine system is often referred to as being affected by aging, because age alters the function of many endocrine glands, including the thyroid (50). As has been previously observed $(15,51)$, in the present study, free serum T4 and T3 decreased slightly but not significantly with aging. Concurrently, serum TSH level rose significantly $(+39 \%)$ even if it remained within the laboratory reference range. These results were in agreement with previous studies of Ravaglia et al. (15) and Hollowell et al. (10) (NHANES III), who reported that TSH and the prevalence of anti-thyroid antibodies increases with age. Serum TSH responds with amplification to minor alterations in $\mathrm{T} 3$ and $\mathrm{T} 4$. Thus elevation of TSH, even when inside normal laboratory values, probably indicates that $\mathrm{T} 3$ and $\mathrm{T} 4$ have been modified. Samuels (52) and Andersen et al. (53) reported that many older patients have abnormal TSH levels without other alterations in serum thyroid hormone levels, conditions they termed subclinical hypothyroidism. Such a status, with elevated TSH, is sometimes also called compensated hypothyroidism (54). Moreover, a logit model indicated that increasing values of serum TSH above $2 \mathrm{mUI} / \mathrm{l}$ at first survey increased the probability of developing hypothyroidism (55). The present results were coherent with this thyroid status, which is difficult to diagnosis because symptoms are subtle and very often attributed to normal aging (56). The intra-subject variability in TSH concentrations suggests another consequence of the aging process: the increased physiological heterogeneity of elderly subjects (57). The significant decrease in the TTR concentration observed in the elderly supported the idea that alterations of thyroid status occur with aging in that TTR is a plasmatic protein that binds and carries the thyroid hormones in the circulating system (58). The increased TSH concentration was probably a sign of subtle dysfunction in the regulation of the thyroid hormone production occurring with advancing age. Moreover, as previously described, hypothyroidism is frequently associated with an elevation in serum cholesterol and triglycerides (59). Subclinical hypothyroidism was also associated with higher concentrations of triglycerides (60) explaining perhaps, at least in part, the observation of an increase in serum triglycerides in the elderly in this study. The age-related increase in TC concentration could be associated with an attenuated thyroid status in the elderly since the regulation of cholesterol metabolism was T3 dependent $(61,62)$. Therefore, even if FT3 appeared unmodified in the elderly subject, its action is mediated by means of TR, the expression of which was decreased. Efstathiadou et al. (63) have reported that the composition and transport of lipoproteins are disturbed in thyroid diseases.

\section{Expression of thyroid nuclear receptors}

Measurement of the expression of thyroid nuclear receptors at the mRNA level, in PBMC, confirmed that irregularities in thyroid function take place with aging. Indeed, TR $\beta$ and, to a lesser extent, TR $\alpha$ were significantly decreased in the elderly as compared with young subjects.

The TR $\beta$ receptors are the most potent regulators of TSH production (64). Thus the decreased expression of TR $\beta$ could explain, in part, the increase in TSH concentration in the elderly. Thyroid hormone regulation of nuclear TR in human lymphocytes has already been demonstrated by Li et al. (65). Sadow et al. (66) have reported that TR isoforms are auto-regulated transcription factors that function in a tissue-specific manner. TR $\alpha$ and TR $\beta$ subtypes can mediate an opposite response to thyroid hormones. The present results confirm the good correlation between free T3 in the plasma and the amount of mRNA of TR $\beta$, but not TR $\alpha$, in the young group $(r=0.60, P=0.022)$, which vanished in the elderly $(r=0.1, P=0.66)$. A similar relationship, which disappeared in the elderly, existed in the YG between the molar ratio RBP:TTR and the abundance of TR $\beta$ mRNA (YG, $r=-0.62, P=0.03 ; \quad$ EG, $r=0.04, P=0.87)$. Together, all these results suggest that the decreased expression of TR is the result of an age-related reduction of the bioavailability of thyroid hormones, particularly T3, at the nuclear level. As we have already suggested for the retinoid pathway, this phenomenon would lead to hypo-activation of the nuclear thyroid pathway.

The results obtained in the present study are the first evidence for an age-related hypo-expression of retinoid and thyroid nuclear receptors, in human PBMC. However the functional implications of the observed changes remain difficult to clarify.

Concerning the consequences of such modifications in PBMC, it is known that a diminution of immune responsiveness occurs in the elderly (67). Moreover, considering that all trans retinoic acid is able to stimulate the immune system through mechanisms involving RAR (68), it is possible to assume that the agerelated hypo-expression of the retinoid receptors is involved in a decrease of the cell cycle machinery and proliferation of normal human lymphocytes. Elsewhere, a lower immune responsiveness has also been observed in vitamin A deficient animals, which exhibited a hypofunction of the retinoid signalling pathway $(69,70)$. Previous studies performed in several animals tissues have emphasized that aging leads to hypo-expression of the nuclear retinoid and thyroid pathways, indicating that thyroid and retinoid status are altered with 
aging, in the entire organism $(33,34)$. Hence, it is possible that alterations in retinoid and thyroid receptors observed in PBMC of the elderly may also occur during aging of other human organs. Among these organs, the brain might be particularly exposed. Indeed, it has been shown in animals that retinoid, as well as thyroid, status modulates the plasticity of the adult brain $(24,71)$ and that their age-associated alteration induces cognitive impairment (72). Moreover, high serum TSH level has been associated with depression in the elderly (73) and hypothyroidism is well known to induce cognitive impairment and dementia $(74,75)$. The role of retinoids in brain aging seems of primary importance itself, in that evidence for defective retinoid transport and function in late-onset Alzheimer's disease has been published (16). Recently, data showing that a disruption of the retinoid signalling pathway causes a deposition of amyloid beta in the adult rat brain have been published (76).

\section{Conclusion}

The present investigation, performed in human PBMC demonstrates that hypo-activity of not only the thyroid, but also the retinoid, signalling pathway occurs with aging; and this hypo-activity is not perceptible from plasma parameters measurements. However, it is not possible to conclude with surety if these results are predictive of the retinoid and thyroid status in the whole organism. Nevertheless, the determination of the evolution of the retinoid and thyroid signalling pathways in the elderly brain is of crucial importance, and it remains to be determined whether the modifications observed in PBMC are relevant for brain functions.

\section{Acknowledgements}

This research was supported by a grant from the Institut National de la Recherche Agronomique (INRA), from the Conseil Régional d'Aquitaine and from the Institut de Recherche en Nutrition humaine en Aquitaine (IRNHA). The Three City Study is conducted under a partnership agreement between the Institut National de la Santé et de la Recherche Médicale (INSERM), the Victor Segalen œ Bordeaux II University and the Sanofi-Synthélabo Company. The Fondation pour la Recherche Médicale funded the preparation and initiation of the study. The Three City Study is also supported by the Caisse Nationale Maladie des Travailleurs Salariés, Direction Générale de la Santé, Conseils Régionaux of Aquitaine and Bourgogne, Fondation de France, Ministry of Research-INSERM Programme 'Cohortes et collections de données biologiques'. This research was also supported by a grant from L' Institut de la Longévité et du Vieillissement.
The authors wish to thank K Mayo for English revision.

\section{References}

1 Schneider G. Aging in the third millenium. Science $1999 \mathbf{5 4 0 3}$ 283-796.

2 Maggi S, Zucchetto M, Grigoletto F, Baldereschi M, Candelise L, Scarpini E, Scarlato G \& Amaducci L. The Italian Longitudinal Study on Aging (ILSA): design and methods. Aging 19946 464-473.

3 Alperovitch A, Amouyel P, Dartigues JF, Ducimetiere P, Mazoyer B, Ritchie K \& Tzourio C. Epidemiological studies on aging in France: from the PAQUID study to the Three-City study. Comptes Rendus Biologie $2002325665-672$.

4 Partridge L \& Gems D. Mechanisms of aging: public or private? Nature Reviews. Genetics 20023 165-175.

5 Troen BR. The biology of aging. Mount Sinai Journal of Medicine, New York $2003 \mathbf{7 0} 3-22$.

6 Ferrucci L, Cavazzini C, Corsi A, Bartali B, Russo CR, Lauretani F, Ferrucci L, Cavazzini C, Corsi AM, Bartali B, Russo CR, Lauretani F, Bandinelli S \& Guralnik JM. Biomarkers of frailty in older persons. Journal of Endocrinological Investigation $2002 \mathbf{2 5}$ (Suppl 10) 10.

7 Bonnefoy M, Drai J \& Kostka T. Antioxidants to slow aging, facts and perspectives. Presse Medicale 200231 1174-1184.

8 Azais-Braesco V, Winklhoffer-Roob B, Ribalta J, Hanley B, Vasson MP, Brtko J, Brigeluis-Flohe R \& Bronner A. Vitamin A, vitamin $\mathrm{E}$ and carotenoid status and metabolism during aging: functional and nutritional consequences (project proposal). Endocrine Regulations $2000 \mathbf{3 4} 97-98$.

9 Mecocci P, Polidori MC, Troiano L, Cherubini A, Cecchetti R, Pini G, Straatman M, Monti D, Stahl W, Sies H, Franceschi C \& Senin U. Plasma antioxidants and longevity: a study on healthy centenarians. Free Radical Biology and Medicine 200028 1243-1248.

10 Hollowell JG, Staehling NW, Flanders WD, Hannon WH, Gunter EW, Spencer CA \& Braverman LE. Serum TSH, T(4), and thyroid antibodies in the United States population (1988 to 1994): National Health and Nutrition Examination Survey (NHANES III). Journal of Clinical Endocrinology and Metabolism $200287489-499$.

11 Borel P, Mekki N, Boirie Y, Partier A, Alexandre-Gouabau MC, Grolier P, Beaufrere B, Portugal H, Lairon D \& Azais-Braesco V. Comparison of the postprandial plasma vitamin A response in young and older adults. Journals of Gerontology. Series A, Biological Sciences and Medical Sciences 199853 B133-B140.

12 van der Loo B, Labugger R, Aebischer CP, Bachschmid M, Spitzer V, Kilo J, Altwegg L, Ullrich V \& Luscher TF. Age-related changes of vitamin A status. Journal of Cardiovascular Pharmacology $20044326-30$.

13 Haller J, Weggemans RM, Lammi-Keefe CJ \& Ferry M. Changes in the vitamin status of elderly Europeans: plasma vitamins A, E, B-6, B-12, folic acid and carotenoids. SENECA Investigators. European Journal of Clinical Nutrition $1996 \mathbf{5 0}$ (Suppl 2) S32-S46.

14 Finucane P \& Anderson C. Thyroid disease in older patients. Diagnosis and treatment. Drugs Aging 19956 268-277.

15 Ravaglia G, Forti P, Maioli F, Nesi B, Pratelli L, Savarino L, Cucinotta D \& Cavalli G. Blood micronutrient and thyroid hormone concentrations in the oldest-old. Journal of Clinical Endocrinology and Metabolism 200085 2260-2265.

16 Goodman $\mathrm{AB} \&$ Pardee $\mathrm{AB}$. Evidence for defective retinoid transport and function in late onset Alzheimer's disease. PNAS 2003 $1002901-2905$.

17 Diez JJ. Hypothyroidism in patients older than 55 years: an analysis of the etiology and assessment of the effectiveness of therapy. Journals of Gerontology. Series A, Biological Sciences and Medical Sciences 200257 M315-M320. 
18 Diez JJ. Hyperthyroidism in patients older than 55 years: an analysis of the etiology and management. Gerontology $2003 \mathbf{4 9}$ 316-323.

19 Leitol H, Behrends J \& Brabant G. The thyroid axis in aging. Novartis Found Symposium 2002242 193-201.

20 Chuo AM \& Lim JK. Thyroid dysfunction in elderly patients. Annals of the Academy of Medicine, Singapore 200332 96-100.

21 Fukui T, Hasegawa Y \& Takenaka H. Hyperthyroid dementia: clinicoradiological findings and response to treatment. Journal of the Neurological Sciences $2001 \mathbf{1 8 4} 81-88$.

22 Constant EL, de Volder AG, Ivanoiu A, Bol A, Labar D, Seghers A, Cosnard G, Melin J \& Daumerie C. Cerebral blood flow and glucose metabolism in hypothyroidism: a positron emission tomography study. Journal of Clinical Endocrinology and Metabolism 200186 3864-3870.

23 Smith JW, Evans AT, Costall B \& Smythe JW. Thyroid hormones, brain function and cognition: a brief review. Neuroscience and Biobehavioral Reviews 200226 45-60.

24 Bernal J. Action of thyroid hormone in brain. Journal of Endocrinological Investigation 200225 268-288.

25 Sporn MB, Roberts AB \& Goodman D. The Retinoids: Biology, Chemistry, and Medicine. New York: Raven Press Editor, 1994.

26 Marill J, Idres N, Capron CC, Nguyen E \& Chabot GG. Retinoic acid metabolism and mechanism of action: a review. Current Drug Metabolism 20034 1-10.

27 Aranda A \& Pascual A. Nuclear hormone receptors and gene expression. Physiological Reviews 200181 1269-1304.

28 Yen PM. Physiological and molecular basis of thyroid hormone action. Physiological Reviews 200181 1097-1142.

29 Viguerie $N$ \& Langin D. Effect of thyroid hormone on gene expression. Current Opinion in Clinical Nutrition and Metabolic Care 20036 377-381.

30 Schrader M \& Carlberg C. Thyroid hormone and retinoic acid receptors form heterodimers with retinoid $\mathrm{X}$ receptors on direct repeats, palindromes, and inverted palindromes. DNA and Cell Biology 199413 333-341.

31 Mangelsdorf DJ \& Evans RM. The RXR heterodimers and orphan receptors. Cell $199583841-850$.

32 Li D, Li T, Wang F, Tian H \& Samuels HH. Functional evidence for retinoid $X$ receptor $(\mathrm{RXR})$ as a nonsilent partner in the thyroid hormone receptor/RXR heterodimer. Molecular and Cellular Biology 200222 5782-5792.

33 Pallet V, Azais-Braesco V, Enderlin V, Grolier P, Noel-Suberville C, Garcin H \& Higueret P. Aging decreases retinoic acid and triiodothyronine nuclear expression in rat liver: exogenous retinol and retinoic acid differentially modulate this decreased expression. Mechanisms of Ageing and Development 199799 123-136.

34 Enderlin V, Pallet V, Alfos S, Dargelos E, Jaffard R, Garcin H \& Higueret P. Age-related decreases in mRNA for brain nuclear receptors and target genes are reversed by retinoic acid treatment. Neuroscience Letters 1997229 125-129.

35 Folstein MF, Folstein SE \& McHugh PR. 'Mini-mental state'. A practical method for grading the cognitive state of patients for the clinician. Journal of Psychiatric Research $197512189-198$.

36 Leclercq M \& Bourgeay-Causse M. A simple, reliable fast method: simultaneous proportioning of retinol and serum tocopherol by high performance liquid chromatography. Revue Institut Pasteur Lyon 198114 475-496.

37 Redonnet A, Bonilla S, Noel-Suberville C, Pallet V, Dabadie H, Gin H \& Higueret P. Relationship between peroxisome proliferator-activated receptor gamma and retinoic acid receptor alpha gene expression in obese human adipose tissue. International Journal of Obesity and Related Metabolic Disorders 200226 920-927.

38 Almekinder J, Manda W, Soko D, Lan Y, Hoover DR \& Semba RD. Evaluation of plasma retinol-binding protein as a surrogate measure for plasma retinol concentrations. Scandinavian Journal of Clinical and Laboratory Investigation 200060 199-203.
39 de Pee S \& Dary O. Biochemical indicators of vitamin A deficiency: serum retinol and serum retinal binding protein. Journal of Nutrition 2002132 2895S-2901S.

40 Zago LB, Dupraz H. Sarchi MI \& Rio ME. The molar ratio of retinol-binding protein to transthyretin in the assessment of vitamin A status in adults. Proposal of a cut-off point. Clinical Chemistry and Laboratory Medicine 200240 1301-1307.

41 Rosales FJ, Chau KK, Haskell MH \& Shankar AH. Determination of a cutoff value for the molar ratio of retinol-binding protein to transthyretin (RBP:TTR) in Bangladeshi patients with low hepatic vitamin A stores. Journal of Nutrition 2002132 3687-3692.

42 Gardner EM, Bernstein ED, Dorfman M, Abrutyn E \& Murasko DM. The age-associated decline in immune function of healthy individuals is not related to changes in plasma concentrations of beta-carotene, retinol, alpha-tocopherol or zinc. Mechanisms of Ageing and Development 199794 55-69.

43 Garry PJ, Hunt WC, Bandrofchak JL, VanderJagt D \& Goodwin JS. Vitamin A intake and plasma retinol levels in healthy elderly men and women. American Journal of Clinical Nutrition $1987 \mathbf{4 6}$ 989-994.

44 Goodman DS. Plasma retinol-binding protein. Annals of the New York Academy of Sciences $1980 \mathbf{3 4 8} 378-390$.

45 Hercberg S, Preziosi P, Galan P, Devanlay M, Keller H, Bourgeois C, Potier de Courcy G \& Cherouvrier F. Vitamin status of a healthy French population: dietary intakes and biochemical markers. International Journal for Vitamin and Nutrition Research $19946 \mathbf{6 4}$ $220-232$.

46 Ingenbleek Y \& De Visscher M. Hormonal and nutritional status: critical conditions for endemic goiter epidemiology? Metabolism 197928 9-19.

47 Robbins J. Transthyretin from discovery to now. Clinical Chemistry and Laboratory Medicine 200240 1183-1190.

48 Watson RE, Arjuna Ratnayaka J, Brooke RC, Yee-Sit-Yu S, Ancian P \& Giffiths E. Retinoic acid receptor alpha expression and cutaneous ageing. Mechanisms of Ageing and Development 2004125 465-473.

49 Furr HC. Analysis of retinoids and carotenoids: problems resolved and unsolved. Journal of Nutrition $2004134281 S-285$ S.

50 Corrêa da Costa VM, Moreira DG \& Rosenthal D. Thyroid function and aging: gender-related differences. Journal of Endocrinology 2001171 193-198.

51 Magri F, Muzzoni B, Cravello L, Fioravanti M, Busconi L, Camozzi D, Vignati G \& Ferrari E. Thyroid function in physiological aging and in centenarians: possible relationships with some nutritional markers. Metabolism 200251 105-109.

52 Samuels MH. Subclinical thyroid disease in the elderly. Thyroid $19988803-813$.

53 Andersen S, Bruun NH, Pedersen KM \& Laurberg P. Biologic variation is important for interpretation of thyroid function tests. Thyroid $2003131069-1078$.

54 Benediktsson R \& Toft AD. Management of the unexpected result: compensated hypothyroidism. Postgraduate Medical Journal 1998 $74729-732$.

55 Vanderpump MP, Tunbridge WM, French JM, Appleton D, Bates D, Clark F, Grimley Evans J, Hasan DM, Rodgers H, Tunbridge F \& Young ET. The incidence of thyroid disorders in the community: a twenty-year follow-up of the Whickham Survey. Clinical Endocrinology $1995 \mathbf{4 3} 5-68$.

56 Mohandas R \& Gupta KL. Managing thyroid dysfunction in the elderly. Answers to seven common questions. Postgraduate Medicine $200311354-56$.

57 Evans JG. Aging and disease. Ciba Foundation Symposium 1988 $13438-57$.

58 Schreiber G. The evolutionary and integrative roles of transthyretin in thyroid hormone homeostasis. Journal of Endocrinology $200217561-73$.

59 Duntas LH. Thyroid disease and lipids. Thyroid 200212 287-293.

60 Kvetny J, Heldgaard PE, Bladbjerg EM \& Gram J. Subclinical hypothyroidism is associated with a low-grade inflammation, 
increased triglyceride levels and predicts cardiovascular disease in males below 50 years. Clinical Endocrinology $200461232-238$.

61 Gullberg H, Rudling M, Forrest D, Angelin B \& Vennstrom B. Thyroid hormone receptor beta-deficient mice show complete loss of the normal cholesterol 7alpha-hydroxylase (CYP7A) response to thyroid hormone but display enhanced resistance to dietary cholesterol. Molecular Endocrinology $2000 \quad 14$ 1739-1749.

62 Macchia PE, Takeuchi Y, Kawai T, Cua K, Gauthier K, Chassande O, Seo H, Hayashi Y, Samarut J, Murata Y, Weiss RE \& Refetoff S. Increased sensitivity to thyroid hormone in mice with complete deficiency of thyroid hormone receptor alpha. PNAS 200198 349-354.

63 Efstathiadou Z, Bitsis S, Milionis HJ, Kukuvitis A, Bairaktari ET, Elisaf MS \& Tsatsoulis A. Lipid profile in subclinical hypothyroidism: is L-thyroxine substitution beneficial? European Journal of Endocrinology $2001 \mathbf{1 4 5} 705-710$.

64 Gauthier K, Chassande O, Plateroti M, Roux JP, Legrand C, Pain B, Rousset B, Weiss R, Trouillas J \& Samarut J. Different functions for the thyroid hormone receptors TRalpha and TRbeta in the control of thyroid hormone production and post-natal development. EMBO Journal 199918 623-631.

65 Li DQ, Kuang AK, Ding T, Chen JL \& Xu MY. Nuclear 3,5,3'-triiodothyronine receptors (T3R) of circulating human lymphocytes in hyper- and hypothyroidism and nonthyroidal diseases. Chinese Medical Journal (English) 1990103 355-358.

66 Sadow PM, Chassande O, Koo EK, Gauthier K, Samarut J, Xu J, O'Malley BW \& Weiss RE. Regulation of expression of thyroid hormone receptor isoforms and coactivators in liver and heart by thyroid hormone. Molecular and Cellular Endocrinology 2003 $20365-75$.

67 Linton PJ \& Dorshkind K. Age-related changes in lymphocyte development and function. Nature Immunology 20045 133-139.

68 Ertesvag A, Engedal N, Naderi S \& Blomhoff HK. Retinoic acid stimulates the cell cycle machinery in normal T cells: involvement of retinoic acid receptor-mediated IL-2 secretion. Journal of Immunology 2002169 5555-5563.

69 Sijtsma SR, Rombout JH, Kiepurski A, West CE \& van der Zijpp AJ. Changes in lymphoid organs and blood lymphocytes induced by vitamin A deficiency and Newcastle disease virus infection in chickens. Developmental and Comparative Immunology 199115 349-356.

70 van Bennekum AM, Wong Yen Kong LR, Gijbels MJ, Tielen FJ, Roholl PJ, Brouwer A \& Hendriks HF. Mitogen response of B cells, but not $\mathrm{T}$ cells, is impaired in adult vitamin A-deficient rats. Journal of Nutrition 1991121 1960-1968. Erratum in Journal of Nutrition $1992 \mathbf{1 2 2} 588$.

71 Husson M, Enderlin V, Alfos S, Féart C, Higueret P \& Pallet V. Triiodothyronine administration reverses vitamin A deficiencyrelated hypo-expression of retinoic acid and triiodothyronine nuclear receptors and of neurogranin in rat brain. British Journal of Nutrition 200390 191-198.

72 Etchamendy N, Enderlin V, Marighetto A, Vouimba RM, Pallet V, Jaffard R \& Higueret P. Alleviation of a selective age-related relational memory deficit in mice by pharmacologically induced normalization of brain retinoid signalling. Journal of Neurosciences $2001216423-6429$.

73 Chueire VB, Silva ET, Perotta E, Romaldini JH \& Ward LS. High serum TSH levels are associated with depression in the elderly. Archives of Gerontology and Geriatrics 200336 281-288.

74 Manciet G, Dartigues JF, Decamps A, Barberger-Gateau P, Letenneur L, Latapie MJ \& Latapie JL. The PAQUID survey and correlates of subclinical hypothyroidism in elderly community residents in the southwest of France. Age Aging $1995 \mathbf{2 4}$ $235-241$.

75 Davis JD, Stern RA \& Flashman LA. Cognitive and neuropsychiatric aspects of subclinical hypothyroidism: significance in the elderly. Current Psychiatry Reports 20035 384-390.

76 Corcoran JP, So PL \& Maden M. Disruption of the retinoid signalling pathway causes a deposition of amyloid beta in the adult rat brain. European Journal of Neurosciences 200420 896-902.

Received 15 September 2004

Accepted 26 November 2004 